\title{
PERBERDAYAAN KELOMPOK MASYARAKAT MELALUI EKPLORASI BENIH POHON HUTAN DI DESA KARANGSARI KABUPATEN KUNINGAN JAWA BARAT
}

\author{
Agus Yadi Ismail ${ }^{1}$, Ilham Adhya ${ }^{1}$, Dede Kosasih ${ }^{1}$, Angga Adi Nugraha ${ }^{2}$, \\ Fizar Ali Sudrajat ${ }^{2}$ \\ ${ }^{1}$ Dosen Fakultas Kehutanan Universitas Kuningan \\ ${ }^{2}$ Mahasiswa Fakultas Kehutanan Universitas Kuningan \\ E-mail: agus.yadi@uniku.ac.id
}

\begin{abstract}
Abstrack
Forest and land rehabilitation activities in the form of tree planting are increasingly in demand. However, the availability of seed sources that come from good quality seeds is still limited. The goal of empowerment for the community is in the form of training, counseling and the practice of downloading forest plant seeds that can be used for making nurseries. The method used in this activity is counseling, discussion and seed downloading practice. The result of this activity is the transfer of knowledge related to seed downloading, including the selection of the location of the seed garden, the procedure for downloading to the cleaning and sorting of seeds, the Exploration of fruit is carried out on 25 Caliandra spp trees with $1 \mathrm{~kg}$ of wet seed yields. Selection related to seed Exploration techniques and seed Exploration techniques for village communities through village farmer groups around the forest is very much needed in the hope of fulfilling the supply for a nursery that produces good quality seeds for land and forest rehabilitation activities so that in the future there is a need for further activities related to Exploration seed.
\end{abstract}

Keywords: Seeds, Sources of Seed, Extension, Community Empowerment and Farmer Groups

\begin{abstract}
Abstrak
Kegiatan rehabilitasi hutan dan lahan berupa pertanaman pohon semakin diminati. Namun ketersediaan sumber bibit yang berasal dari mutu benih yang baik masih terbatas .Tujuan dari pemberdayaan kepada masayarakat adalah berupa pelatihan ,penyuluhan dan praktek pengunduhan benih tanaman hutan yang dapat digunakan untuk pembuatan persemaian. Metode yang digunakan dalam kegiatan ini adalah penyuluhan,diskusi dan praktek penggunduhan benih. Hasil dari kegiatan ini adalah transfer pengetahuan berkaitan dengan ekplorasi benih meliputi Pemilihan lokasi kebun benih, tata cara ekplorasi sampai pada pembersihan dan sortasi benih, ekplorasi benih dilakukan pada 25 pohon Caliandra spp dengan berat benih yang di hasilkan sebanyak $1 \mathrm{~kg}$ benih basah. Kegiatan Tehnik eksplorasi benih tanaman hutan bagi masyarakat desa sekitar hutan sangat diperlukan dengan harapan dapat memenuhi pasokan untuk penyediaan persemaian yang menghasilkan bibit yang bermutu baik untuk kegiatan rehabilitasi lahan dan hutan sehingga kedepan perlu adanya kegiatan lebih lanjut terkait dengan pengunduhan benih.
\end{abstract}

Kata Kunci: Bibit, Sumber Benih, Penyuluhan, Pemberdayaan masyarakat dan Kelompok tani

\section{PENDAHULUAN}

Perbenihan tanaman hutan adalah segala sesuatu yang berkaitan dengan pembangunan sumberdaya genetik, pemuliaan tanaman hutan, pengadaan dan pengedaran benih dan bibit, dan sertifikasi. Benih tanaman hutan yang selanjutnya disebut benih adalah bahan tanaman berupa bahan generatif (biji) atau bahan vegetatif yang digunakan untuk mengembangbiakkan tanaman hutan. Bibit tanaman hutan yang selanjutnya disebut bibit adalah tumbuhan muda hasil pengembangbiakan secara generatif atau secara vegetatif. Sumber benih adalah suatu tegakan di dalam di dalam kawasan hutan dan di luar kawasan hutan yang dikelola guna memproduksi benih berkualitas (Permenhut, 2009). 
Kawasan Blok Karangsari Taman Nasional Gunung Ciremai (TNGC) merupakan salah satu dari zona rehabilitasi yang mempunyai tutupan lahan sebagian besar adalah tegakan Pinus merkusii. Berdasarkan hasil wawancara dengan masyarakat sejak Tahun 2014 kegiatan rehabilitasi pada blok ini telah dilakukan dengan menanam beberapa jenis tanaman rehabilitasi diantaranya beunying, walen, dan pulai. Untuk memenuhi kebutuhan rehabilitasi kawasan yaitu dengan ditaminya kembali maka diperlukan bibit pohon-pohon rehabilitasi yang berasal dari benih dari alam. Dalam pengadaan persemaian hal penting dan harus diperhatikan adalah kegiatan pengadaan benih yang berasal dari alam. Kegiatan ini dinamakan pengunduhan benih. Kegiatan pengadaan benih mencakup pencarian, pemanenan/pengunduhan, pengumpulan, ekstraksi benih, pembersihan, seleksi, dan penyimpanan.

Ketersedian benih bermutu dalam jumlah yang cukup sangat ditentukan oleh musim berbuah setiap tanaman, sedangkan musim berbuah setiap jenis tanaman dipengaruhi oleh iklim. Unsur-unsur iklim terutama temperatur, kelembaban dan intensitas cahaya matahari akan mempengaruhi proses pemasakan buah. Pengunduhan buah pada awal masak fisiologis kurang tepat karena buah yang dipanen belum cukup berkembang sebaliknya pengunduhan buah pada akhir masak fisiologis juga kurang tepat karena buah yang dipanen dapat menyebabkan penurunan kualitas benih.Buah yang dipanen tepat waktu atau pada saat masak fisiologis akan menghasilkan benih yang berkualitas lebih baik dibandingkan dengan buah yang dipanen pada awal dan akhir masak fisiologis. Masak fisiologis akan menentukan waktu pengunduhan dan kualitas buah yang dipanen (Perotti, V. E., Moreno, A.S., \& Podesta,F.E.,2014).

Menurut Schimidt (2000), waktu panen atau pengunduhan buah akan menentukan kualitas benih. Buah yang dipanen pada awal maupun akhir masak fisiologis sering menghasilkan benih dengan kualitas fisiologis maupun biokimia yang rendah sehingga menghasilkan benih yang kurang berkualitas. Beberapa penelitian terhadap kematangan buah menegaskan bahwa tingkat kematangan buah berpengaruh nyata pada perkecambahan biji, seperti pada jenis Ardisia spp (Normasiwi, 2013). Oleh sebab itu penulis akan melakukan kegiatan pengabdian pada masyarakat dengan tema "Penyuluhan Teknik Pengunduhan Benih Hutan di Desa Karangsari Kecamatan Darma Kabupaten Kuningan". Dalam upaya rehabilitasi lahan dan hutan kendala yang sering di hadapi adalah ketersediaan bibit tanaman rehabilitasi yang siap tanam. Sampai saat ini kelompok tani hanya memanfaatkan bibit tanaman rehabilitasi dari penyedia bibit (pedagang), hal ini terjadi karena para petani mempunyai keterbatasan pengetahuan dalam pengunduhan benih tanamah hutan untuk memperoleh bibit yang berkualitas ,sehingga diperlukan upaya pelatihan terkait dengan tehnik pengunduhan benih tanaman hutan.

Luaran yang dihasilkan dari kegiatan pengabdian kepada masyarakat ini adalah diperolehnya pengetahuan teknik pengunduhan benih tanaman hutan untuk kegiatan pembuatan bibit di persemaian. Luaran lainnya adalah publikasi jurnal. Dampak sosial dengan adanya penyuluhan dan praktek pengunduhan benih tanaman hutan adalah bagi kelompok adalah meningkatnya pengetahuan dan kemampuan kelompok tani dalam kegiatan pengunduhan benih tanaman hutan di lapangan untuk keperluan pembuatan bibit di persemaian yang dapat diperjualbelikan. 


\section{METODE PELAKSANAAN}

\section{Pendekatan yang Ditawarkan}

Pendekatan yang ditawarkan dalam kegiatan ini adalah melakukan melakukan pelatihan,penyuluhan dan praktek pengunduhan benih tanaman hutan bagi pembuatan bibit di persemaian. Adapun tahapan yang akan dilaksanakan sebagai berikut:

1. Penyuluhan tentang pengenalan jenis-jenis tanaman

Penyuluhan akan dilakukan oleh dosen Fakultas Kehutanan Universitas Kuningan, sehingga diharapkan kelompok dan masyarakat mendapatkan pengetahuan tentang jenis jenis tanaman yang terdapat di lokasi pelatihan.

2. Praktek cara pengunduhan benih

Praktek pengunduhan benih tanaman hutan dilakukan oleh tim Fakultas Kehutanan kepada kelompok/masyarakat dengan melakukan secara langsung di hutan..

\section{Partisipasi Mitra dalam Pelaksanaan Program}

Kegiatan ini melibatkan kelompok/masyarakat sebagai mitra Fakultas Kehutanan Universitas Kuningan dengan harapan semua kegiatan dapat berjalan sesuai dengan tujuan yang telah disepakati. Bentuk keterlibatan masyarakat dalam kegiatan ini berupa pelibatan dalam menyiapkan alat dan bahan yang akan dipraktekkan.

\section{Langkah Evaluasi Pelaksaan dan Keberlanjutan Program}

Kegiatan yang akan dilaksanakan ini merupakan kegiatan jangka panjang sehingga perlu dilakukan evaluasi pada setiap tahapan. Evaluasi program jangka pendek diharapkan masyarakat mampu mendapatkan benih-benih hutan yang bermutu, kemudian dapat menunjang kegiatan dalam pembuatan pengadaan bibit di persemaian. Target jangka panjangnya atau keberlanjutan program ini adalah masyarakat mampu memasarkan benih yang bermutu baik dan bibit berkualitas sehingga dapat mendukung kegiatan rehabilitasi hutan dan lahan dan dapat meningkatkan penghasilan masyarakat.

\section{HASIL DAN PEMBAHASAN}

Kegiatan pengunduhan benih yang berasal dari tanaman hutan merupakan hal yang tak kalah penting, salah satu upaya awal yang harus dilakukan dalam kegiatan penggunduhan benih adalah mengidentifikasi lokasi sumber pohon yang memiliki potensi untuk di lakukan pengunduhan, hal ini bertujuan untuk pemilihan sumber benih yang baik berdasarkan bentuk tegakan atau pohon. Semua usaha yang dilakukan untuk mencari dan memilih sumber benih yang baik akan percuma bila pengumpulan benih tidak dilakukan dengan cara yang benar. Berikut ini beberapa hal yang dilaksanakan dalam kegiatan pengunduhan benih di Kawasan Taman Nasional Gunung Ciremai tepatnya di stasiun riset Fakultas Kehutanan Universitas Kuningan dengan tahapan kegiatan seperti yang terlihat pada gambar di bawah ini (Diadaptasi dari IFSP, 2000). 


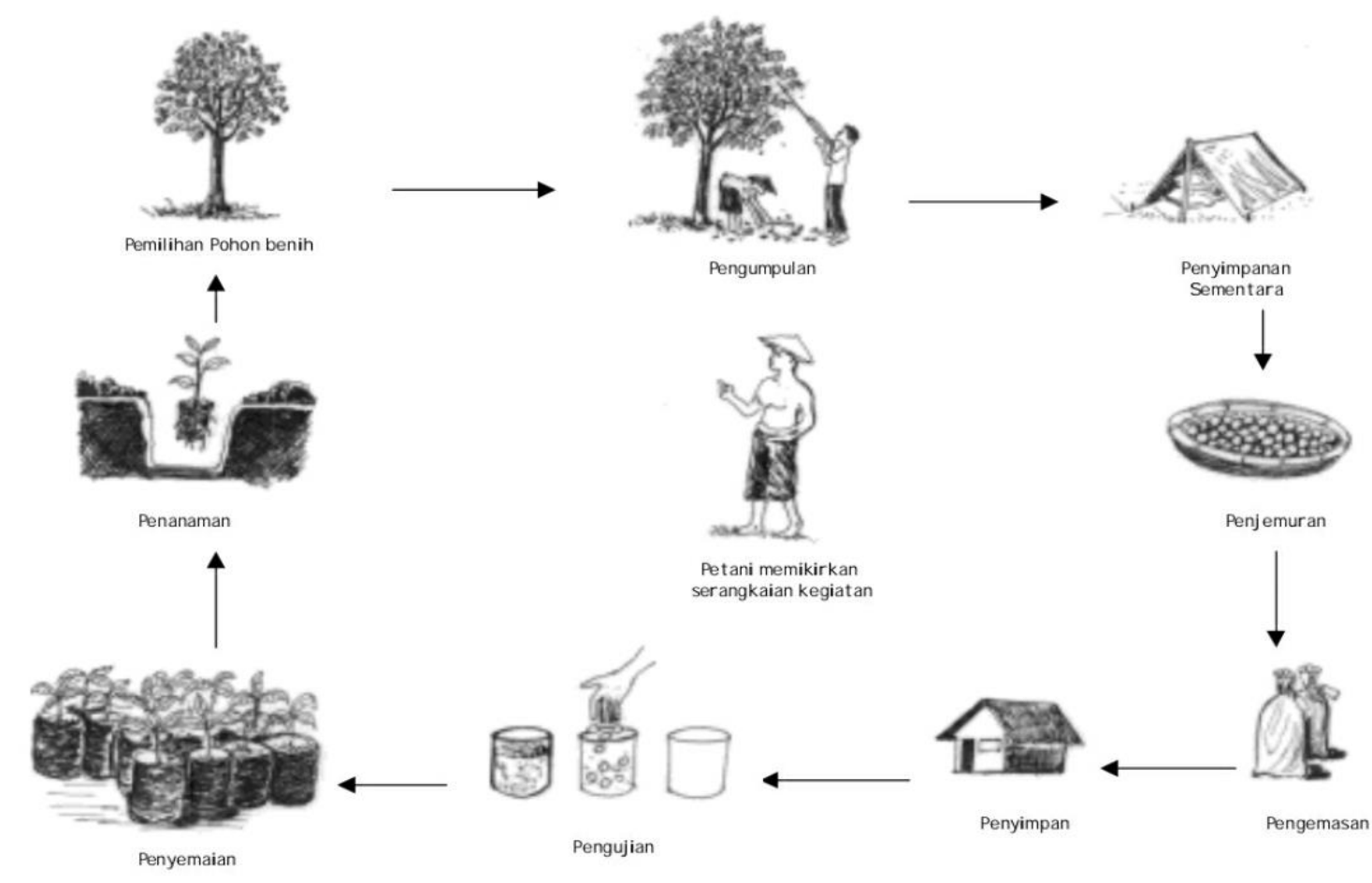

Gambar 1. Tahapan Kegiatan Penggunduhan Benih

Selanjutnya kegiatan penggunduhan benih yang dilaksanakan diawali dengan pemilihan pohon benih di lokasi tegakan yang memiliki potensi benih yang siap untuk di unduh, pemilihan pohon yang akan di unduh benihnya didasarkan pada kriteria yaitu pohon yang diseleksi dari tegakan yang seragam, bentuk yang besar, lurus, sehat, dan memiliki benih yang lebat dan bebas dari hama penyakit. hal ini sejalan dengan pernyataan Setiadi (2017) bahwa Pemilihan lokasi kebun benih beradasarkan Permenhut No: P.72/MenhutII/2009 tanggal 10 Desember 2009 adalah tegakan yang memiliki pohon-pohon dengan kualitas fenotipik superior (batang lurus, tidak cacat dan percabanagnnya ringan), diketahui komposisi jenisnya, jumlah pohon induk minimal 25 pohon dengan bobot benih yang dihasilkan sebanyak $1 \mathrm{Kg}$. Sedangkan Langkah selanjutnya terkait dengan tehnik penggunduhan benih tanaman hutan adalah pengambilan buah yang berasal dari pohon terpilih sebanyak 25 pohon kaliandra merah (Calliandra calothyrsus) dan kaliandra putih (Calliandra tetragona) yang telah di identifikasi sesuai kriteria sebagai sumber benih. pohon yang terpilih untuk dilakukan penggunduhan atau Pengumpulan dapat dilakukan dengan dua cara penggunduhan yaitu dengan cara menarik cabang pohon apabila pohon tersebut memiliki buah atau benih masak tidak terlalu tinggi dan buah/benih yang masak dapat bisa dicapai dari tanah secara langsung atau relative pendek, sedangkan cara selanjutnya dengan memanjat pohon, cara ini dilakukan apabila buah atau benih yang masak tidak bisa dijangkau dari tanah. Lebih jelasnya bisa dilihat pada gambar 2 dan 3. 


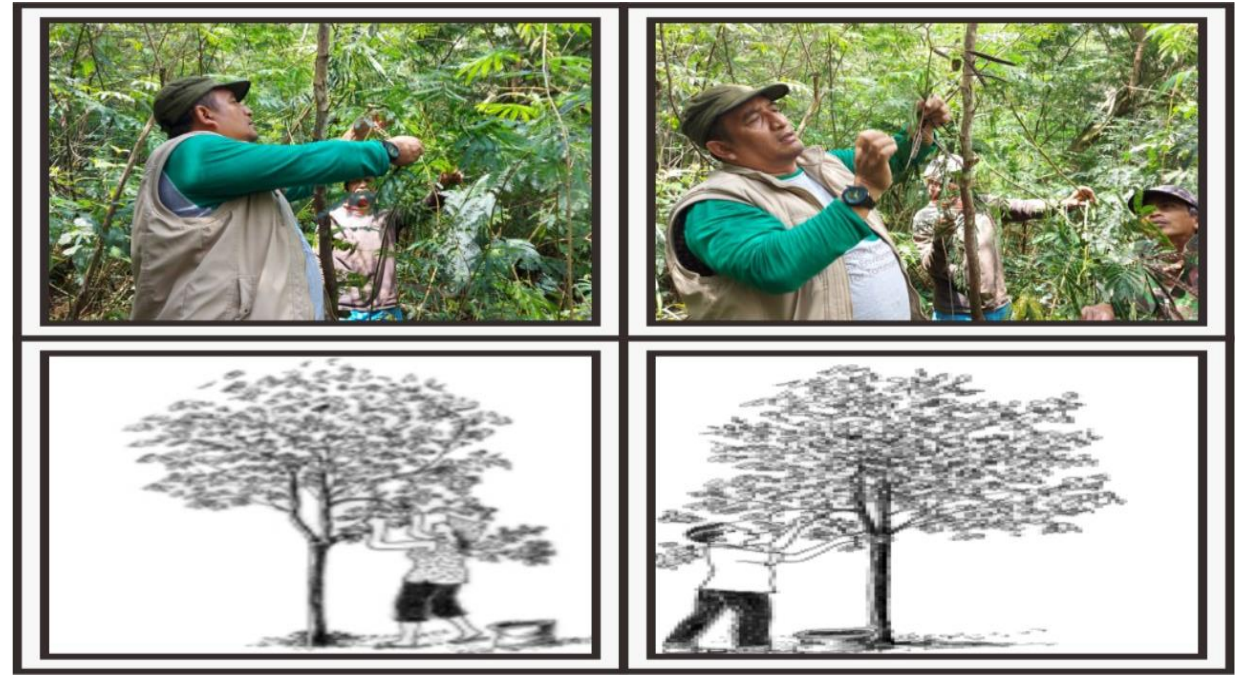

Gambar 2. Penggunduhan Buah atau benid dengan cara menarik cabang

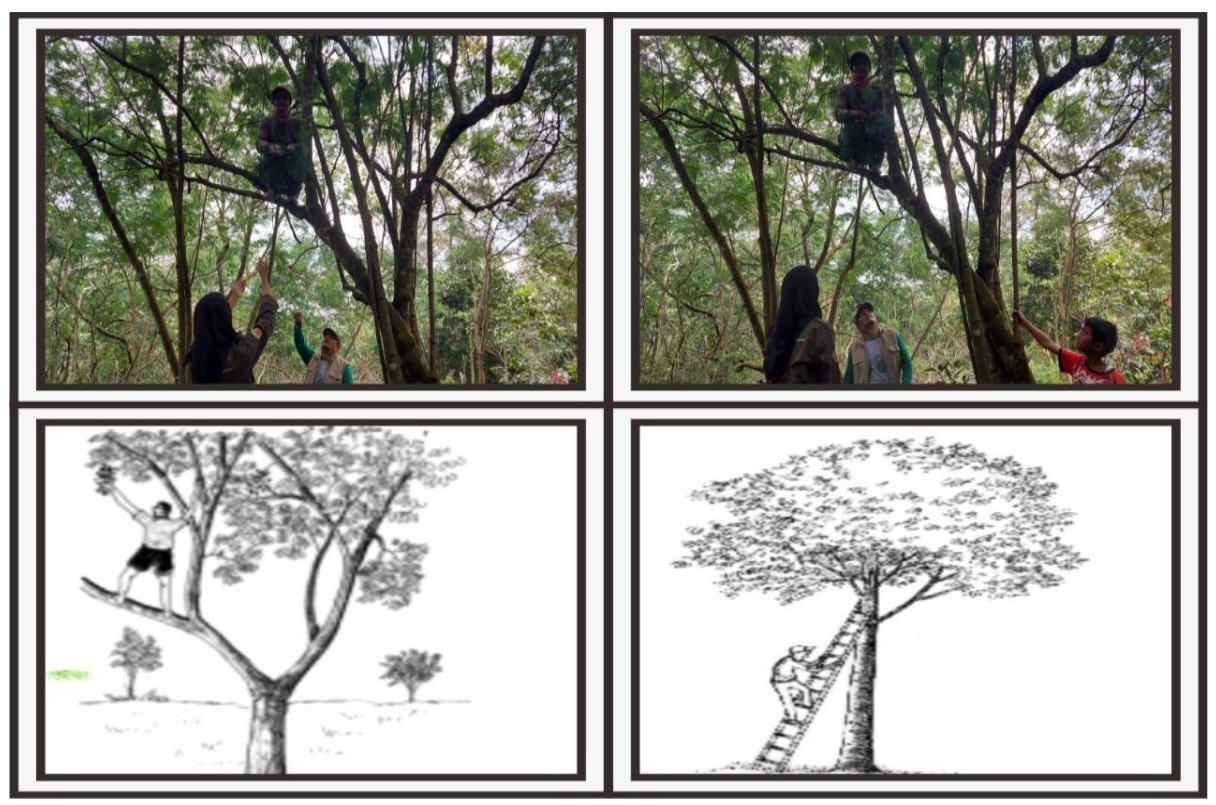

Gambar 3. Penggunduhan Buah atau Benih tanaman dengan cara di panjat

Selanjutnya setelah dilakukan pengunduhan, tahapan selanjutnya adalah melakukan pengumpulan benih yang di tempatkan pada karung goni atau plastik lalu di beri identitas atau pelabelan berupa informasi asal pohon, berat buah/polong, asal benih, label identitas (penomeran hasil koleksi) hal ini dimaksudkan untuk mempermudah identifikasi asal benih..adapun bentuk label atau identitas disesuaikan dengan yang dilakukan IFSC (2010) seperti gambar di bawah ini 


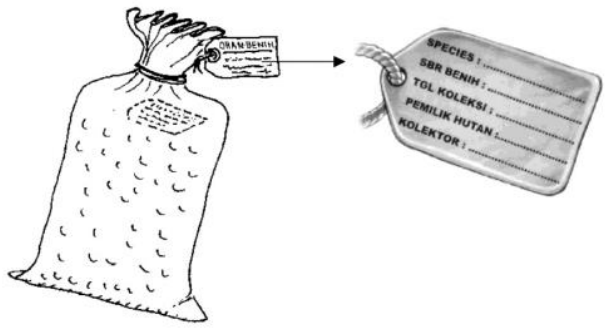

Gambar 4. Label Karung Tempat Pengumpulan Buah atau Benih

Selanjutnya benih yang sudah terkumpul tersebut dilakukan kegiatan sebagi berikut :

1. Sortasi buah,

Buah atau polong yang sudah tua dan matang dipisahkan dengan yang kurang matang kemudian di masukan kedalam wadah yang terpisah.

2. Ekstraksi benih,

Adalah proses pengeluaran biji dari polongnya, ektaraksi biji bisa dilakukan dengan beberapa cara yaitu bisa langsung di keluarkan dari polongnya, di gosok dengan menggunakan abu atau di pukul dengan hati- hati biji yang dimpan dalam karung

3. Pembersihan benih

Benih atau biji yang sudah di ektraksi masih mengandung kotoran berupa sisa polong,ranting dan lain sebagianya maka kegiatan pembersihan benih harus dilakukan pembersihan benih dilakukan dengan cara di manual menggunakan tampi.

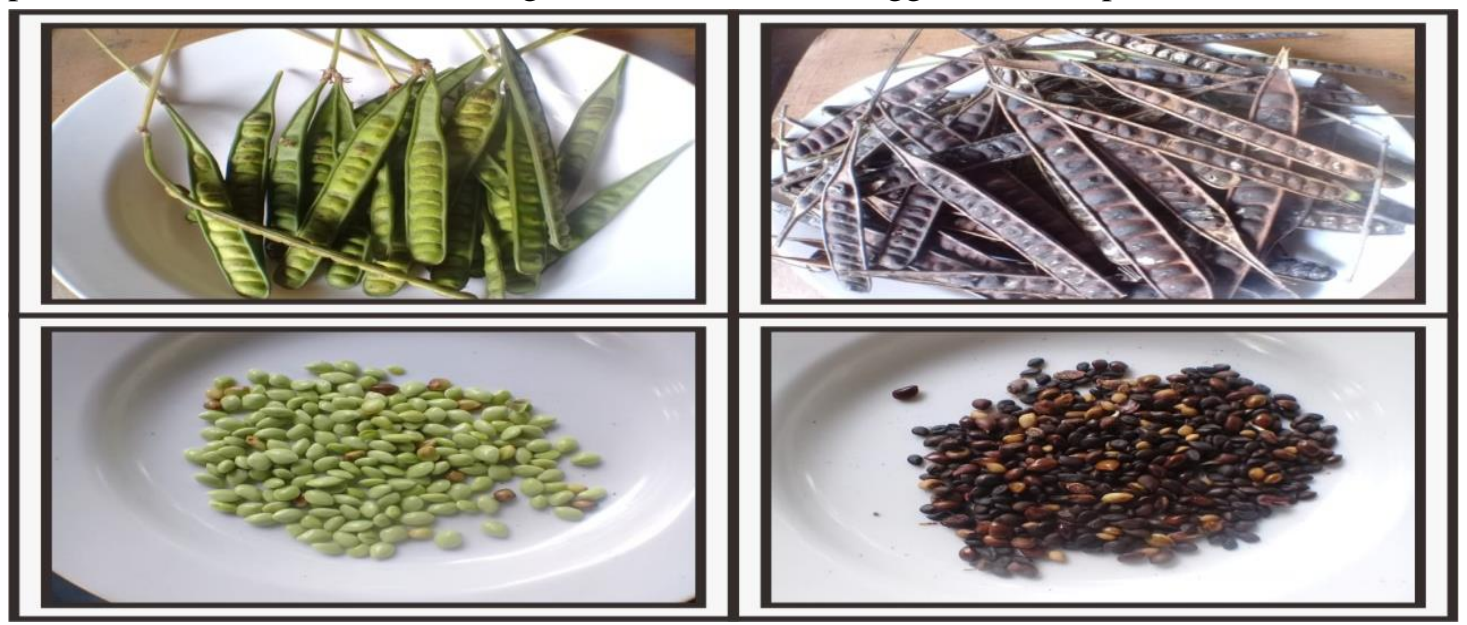

Gambar 5. Polong/Benih Kalindara merah dan Putih

4. Sortasi benih,

Sortasi benih merupakan tahapan pemilihan benih berdasarkan tangka ketangan,Kesehatan dan bentuk dari benih itu sendiri.

5. Pengeringan benih,

Pengeringan benih dilakukan apabila benih yang sudah di sortasi atau dipilih. Pengeringan bertujuan untuk menghilangkan kadar air yang ada dalam benih, pengeringan benih dilakukan dengan cara di kering anginkan atau di jemur di bawah terik matahari

6. Penyimpanan Benih

Penyimpanan benih dilkukan apabila proses pengeringan sudah dilakukan oleh seba itu benih harus dilakukan, penyimpanan benih setelah proses pengeringan dengan menggunakan karung goni atau plastik 


\section{SIMPULAN}

Kegiatan Pengabdian kepada Masayarakat yang telah dilaksanakan di desa Karangsari Kecamatan Darma Kabupaten Kuningan, telah selesai dilaksanakan sesuai dengan tahapan kegiatan tehnik penggunduhan benih tanaman hutan mulai dari pemilihan lokasi, pengunduhan, pengumpulan,ektraksi,sortasi, pengeringan dan penyimpanan benih benih telah dilaksanakan dengan baik, secara umum kelompok Penggiat Pariwisata menyambut baik kegiatan tersebut dan diharapkan kegiatan ini bisa terus berlanjut dalam upaya meningkatkan pengetahuan dan tarap hidup masayarakat.

\section{SARAN}

Diharapakan kegiatan seperti ini bisa dilaksanakan secara berkelanjutan mulai dari kegitan pemilihan sumber benih, tehnik penggunduhan sampai pada sortasi dan pemasaran benih oleh kelompok tani.sehingga peningkatan kesejahteraan masyarakat desa hutan umumnya bisa terpenuhi dari hasil hutan non kayu seperti benih yang memiliki peluang pasar di masa depan.

\section{UCAPAN TERIMA KASIH}

Penulis mengucapkan terima kasih kepada LPPM Universitas Kuningan, Rektor Universitas Kuningan, Dekan Fahutan Universitas Kuningan dan semua pihak untuk segala dukungan yang telah diberikan sehingga kegiatan pengabdian kepada masyarakat ini dapat terselenggara dengan baik.

\section{DAFTAR PUSTAKA}

Arihidayanto, 2010. Modul Sertifikasi Benih. Direktorat Pembinaan Sekolah Menegah Kejuruan Kementrian Kebudayaan Republik Indonesia.

IFSP. 2000. Demo room poster. Indonesian Forest Seed Project, Bandung.

IFSP. 2000. Visual presentation of extension material. Indonesia Forest Seed Project, Bandung. Jam'an, D.F. 1996. Pengaruh Tingat Kematangan Polong dan Skarifikasi Benih Sengon Buto terhadap Perkecambahannya. Buletin Teknologi Perbenihan. Vol. 3. No. 3. Bogor.

Khurana, E. And J. S. Singh. 2001. Ecology of Tree Seed and Seedlings: Implication for Tropical Forest Conservation and Restoration. Curent Science. 8(6):748-757.

King, R. W. 1982. Abscisic Acid in Seed Development. In A.A. Khan (Ed.). The Physiology and Biochemistry of Seed Development, Dormancy, and Germination. Elsevier Biomedical Press. Amesterdam. New York. Oxford.

Komar, T.E. dan E.R. Kartiana. 1986. Beberapa Perlakuan Pematahan Dormansi Benih Acacia mangium Willd. Laporan Uji Coba No. 9. Balai Teknologi Perbenihan. Bogor.

Lita, S. 2004. Teknologi Benih. PT Raja Grafindo Persada, Jakarta

Normasiwi, S. (2013). Prosiding Ekspose dan Seminar Pembangunan Kebun Raya Daerah Membangun Kebun Raya untuk Penyelamatan Keanekaragaman Hayati dan Lingkungan Menuju Ekonomi Hijau. InTingkat Kematangan Buah dan Pengaruhnya terhadap Perkecambahan Ardisiaspp.(pp 765-771).

Perotti, VE, Moreno, A. and P. F. (2014). Physiological aspect of Fruit ripening. Mitochondrion, 17, 1-6. 
Setiadi, D .(2017). Pembangunan Sumber Benih Genetik Lokal Araucaria cunninghamii di Bondowoso, Jawa Timur. Proceeding Biology Education Conference Volume 14, Nomor 1 Halaman 99 - 105

Schimidt. (2000). Pedoman Penanganan Benih Benih Hutan Tropis dan Sub Tropis. Jakarta: Direktorat Jenderal Rehablitasi Lahan dan Perhutanan Sosial. Departemen Kehutanan.

Wibisono, ITC., Priyanto EB., Suyradiputra, IN. 2006. Panduan Parkatis Rehabilitasi Pantai. Bogor: Wetlands International Indonesian Programme.

Wati, E. 2000. Percobaan Pengaruh Penyimpanan Bibit Terhadap Persentase Hidup Beberapa Jenis Anakan Cabutan Dipterocarpaceae. Buletin Penelitian Kehutanan Vol.14 No.2. h 23- 34. Balai Penelitian Kehutanan Samarinda. 